\title{
The expression and potential function of bone morphogenetic proteins 2 and 4 in bovine trophectoderm
}

\author{
Kathleen A Pennington and Alan D Ealy
}

\begin{abstract}
Background: Bone morphogenetic proteins (BMPs) were first described for their roles in bone formation, but they now also are known to possess additional activities, including those relating to embryogenesis. The objectives of this work were to 1) determine if peri-attachment bovine conceptuses and bovine trophoblast cells (CT1) contain transcripts for BMP2 and 4, an innate inhibitor noggin (NOG), and BMP2/4 receptors (BMPRII, ACVR1, BMPR1A, $B M P R 1 B$ ), and 2) determine if BMP2 or 4 supplementation to $C T 1$ cells affects cell proliferation, differentiation or trophoblast-specific gene expression.
\end{abstract}

Methods: RNA was isolated from day 17 bovine conceptuses and CT1 cells. After RT-PCR, amplified products were cloned and sequenced. In other studies CT1 cells were treated with BMP2 or 4 at various concentrations and effects on cell viability, cell differentiation and abundance of IFNT and CSH1 mRNA were evaluated.

Results: Transcripts for BMP2 and 4 were detected in bovine conceptuses and CT1 cells. Also, transcripts for each BMP receptor were detected in conceptuses and CT1 cells. Transcripts for NOG were detected in conceptuses but not $C T 1$ cells. Cell proliferation was reduced by BMP4 but not BMP2 supplementation. Both factors reduced IFNT mRNA abundance but had no effect on CSH1 mRNA abundance in CT1 cells.

Conclusions: The BMP2/4 ligand and receptor system presides within bovine trophectoderm prior to uterine attachment. BMP4 negatively impacts CT1 cell growth and both BMPs affect IFNT mRNA abundance.

Keywords: Paracrine factor, Placenta, Conceptus, Interferon-tau

\section{Background}

Bone morphogenetic proteins (BMPs) are part of the transforming growth factor- $\beta$ (TGF $\beta$ ) superfamily of paracrine factors $[1,2]$. The BMPs mediate various physiological and developmental processes, including placental development [3]. The BMP4 family of factors, which include BMPs 2 and 4, appear to be especially important in placental development. In the mouse, conceptuses lacking BMP4 undergo developmental arrest at days 6.5-9.5 and lack mesoderm and placental vasculature [4-6]. Mesoderm formation also is absent in mice lacking Bmpr2, the Type II receptor for BMP4 [7]. Interestingly, Bmpr2 null mice have a more severe phenotype than mice lacking BMP4, suggesting the partial

\footnotetext{
* Correspondence: ealy@ufl.edu

Department of Animal Sciences, University of Florida, PO Box 110910,
} Gainesville, FL, USA rescue of the BMP4 null phenotype by other BMPs, such as BMP2 [8].

Bone morphogenetic proteins 2 and 4 also regulate trophoblast lineage development and differentiation. Trophoblast development from human embryonic stem cells is induced by BMP2 and $4[9,10]$. In cattle, BMP4 supplementation improves the formation of trophoblast cell outgrowths from blastocysts [11]. Moreover, trophoblast cell lines generated from these outgrowths produce a multitude of factors, including interferon-tau (IFNT), the maternal recognition of pregnancy factor in ruminants that is secreted from mononucleated cells (MNCs) before placental attachment to the uterine lining [12]. Some of the cell lines derived by BMP4 treatment contain large quantities of IFNT mRNA whereas other lines contain little IFNT and instead contain greater quantities of transcripts detected in differentiated, binucleate

\section{Biomed Central}


cells (BNCs) after placental attachment [11]. It remains unclear if BMP4 may promote trophoblast cell differentiation during culture.

The overall goal of this work was to describe the expression and potential actions of the BMP4 ligandreceptor system during the pre- and peri-attachment period of bovine conceptus development. In the first set of studies, transcript patterns were determined for $B M P 2$, BMP4, noggin (NOG; a BMP2/4 inhibitor) and BMP2/4 receptors (BMPRII, ACVR1, BMPR1A, $B M P R 1 B$ ) in peri-attachment bovine conceptuses (day 17 of gestation) and CT1 cells, a bovine trophoblast cell line that produces IFNT but not BNC marker genes $[13,14]$. In the second set of studies, CT1 cells were treated with BMP2 or 4 to explore whether these factors impact growth, differentiation and gene expression of these cells.

\section{Methods}

\section{Animal use and tissue collection}

All animal use was completed with the approval of the Institutional Animal Care and Use Committee at the University of Florida. Healthy, non-lactating Holstein cows $(\mathrm{n}=12)$ were housed at the University of Florida Dairy Unit (Hague, FL) and fed a diet to meet their maintenance requirements (mixed ration containing corn, soybean meal and haylage along with continuous pasture grazing). Elongated conceptuses were collected at day 17 post-estrus as described previously [15]. In brief, cows were superovulated, bred via artificial insemination and slaughtered by captive bolt trauma and exsanguination at the University of Florida Meats Laboratory at day 17 post-estrus. Reproductive tracts were excised and uterine horns were flushed with Dulbecco's phosphate-buffered saline (DPBS; Life Technologies, Grand Island, NY) to collect conceptuses.

Endometrial samples were collected from non-superovulated cows that were bred and verified pregnant by the presence of a conceptus as described previously [16], and RNA was extracted using the Trizol reagent and PureLink Purification Columns (Life Technologies).

\section{End-point RT-PCR}

RNA concentration and integrity were evaluated using a NanoDrop 2000 Spectrophotometer (Thermo Scientific). Samples (250 ng/reaction; $\mathrm{A}_{260} / 280$ ratio $\geq 1.8$ ) were incubated in RNase-free DNase (New England Biolabs, Ipswich, MA) for $30 \mathrm{~min}$ at $37^{\circ} \mathrm{C}$ followed by heat inactivation for $10 \mathrm{~min}$ at $75^{\circ} \mathrm{C}$. The Superscript III First Strand Synthesis System (Life Technologies) and random hexamers were used for reverse transcription at $50^{\circ}$ $\mathrm{C}$ for $60 \mathrm{~min}$. ThermalAce DNA Polymerase (Life Technologies) was used to amplify DNA ( 35 cycles; $95^{\circ} \mathrm{C}-1$ min, 55 to $59^{\circ} \mathrm{C}$ for $1 \mathrm{~min}$ [depending on the primer pair; Table 1], $\left.74^{\circ} \mathrm{C}-1 \mathrm{~min}\right)$. Non-reverse transcribed DNase-treated RNA was included as a control for genomic DNA contamination. Amplified products were electrophoresed on a $1 \%[\mathrm{w} / \mathrm{v}]$ agarose gel containing 0.5 $\mu \mathrm{g} / \mathrm{ml}$ ethidium bromide and visualized by UV light. Buffer and residual primers were removed from PCR Products by using the PureLink PCR Purification Kit (Life Technologies) and DNA sequencing was completed at the University of Florida DNA Core Facility.

\section{CT1 culture}

The bovine trophectoderm cell line, CT1, previously developed and characterized by Talbot et. al [17] was cultured as described previously [15-17]. In brief, cells were propagated in Dulbecco's Modified Eagle's Medium (DMEM) with high glucose $(5.5 \mathrm{mM})$ containing $10 \%$ fetal bovine serum and other supplements $(100 \mu \mathrm{M}$ non-essential amino acids, $2 \mathrm{mM}$ glutamine, $2 \mathrm{mM}$ sodium pyruvate, $55 \mu \mathrm{M} \beta$-mercaptoethanol, $100 \mathrm{U} / \mathrm{ml}$ penicillin $\mathrm{G}, 100 \mu \mathrm{g} / \mathrm{ml}$ streptomycin sulfate, and 250 $\mathrm{ng} / \mathrm{ml}$ amphoterin $\mathrm{B}$; each from Life Technologies) on Matrigel $^{\mathrm{TM}}$ Basement Membrane Matrix (appr. $1 \mathrm{mg} / \mathrm{ml}$; BD Biosciences, Bedford, MA) at $38.5^{\circ} \mathrm{C}$ in $5 \% \mathrm{CO}_{2}$ in air. Cells were passaged manually by scraping cells from the plates and passing them through a small-bore needle to produce small clumps of cells. On the day before supplementing BMPs, medium was replaced with medium lacking FBS (serum-free medium) and containing a serum substitute (ITS; Life Technologies). All other supplements were kept constant. Serum-free medium was exchanged the next day immediately before adding BMP treatments. Recombinant human (rh) BMP2 or rhBMP4 (R\&D Systems, Minneapolis, MN) was reconstituted according to manufacturer's instructions and stored at

Table 1 Primers used for end-point RT-PCR

\begin{tabular}{|c|c|c|}
\hline Gene of Interest & Primer & Sequence $\left(5^{\prime}-3^{\prime}\right)$ \\
\hline BMP2 & $\begin{array}{l}\text { Forward } \\
\text { Reverse }\end{array}$ & $\begin{array}{l}\text { CTTAGACGGTCTGCGGTCTC } \\
\text { CGAAGCTCTCCCACCTACTG }\end{array}$ \\
\hline BMP4 & $\begin{array}{l}\text { Forward } \\
\text { Reverse }\end{array}$ & $\begin{array}{l}\text { TGAGCCTITCCAGCAAGTTT } \\
\text { TACGATGAAAGCCCTGATCC }\end{array}$ \\
\hline$\overline{N O G}$ & $\begin{array}{l}\text { Forward } \\
\text { Reverse }\end{array}$ & $\begin{array}{l}\text { GAACACCCGGACCCTATCTT } \\
\text { ATGGGGTACTGGATGGGAAT }\end{array}$ \\
\hline BMPRII & $\begin{array}{l}\text { Forward } \\
\text { Reverse }\end{array}$ & $\begin{array}{l}\text { AGACTGTTGGGACCAGGATG } \\
\text { GTCTGGCCCACTGAATTGTT }\end{array}$ \\
\hline ACVR1 & $\begin{array}{l}\text { Forward } \\
\text { Reverse }\end{array}$ & $\begin{array}{l}\text { AAATGGGATCGCTGTACGAC } \\
\text { CTGTGAGTCTGGCAGATGGA }\end{array}$ \\
\hline BMPR1A & $\begin{array}{l}\text { Forward } \\
\text { Reverse }\end{array}$ & $\begin{array}{l}\text { CAGGTTCCTGGACTCAGCTC } \\
\text { CACACCACCTCACGCATATC }\end{array}$ \\
\hline BMPR1B & $\begin{array}{l}\text { Forward } \\
\text { Reverse }\end{array}$ & $\begin{array}{l}\text { AGGTCGCTATGGGGAAGTTT } \\
\text { CTCCCAAAGGATGAGTCCAA }\end{array}$ \\
\hline$\overline{A C T B^{a}}$ & $\begin{array}{l}\text { Forward } \\
\text { Reverse }\end{array}$ & $\begin{array}{l}\text { CTGTCCCTGTATGCCTCTGG } \\
\text { AGGAAGGAAGGCTGGAAGAG }\end{array}$ \\
\hline
\end{tabular}

$\overline{\mathrm{a}}[15]$ 
$-20^{\circ} \mathrm{C}$ in single-use aliquots. All treatments were prepared in $0.1 \%[\mathrm{w} / \mathrm{v}]$ BSA solution in DMEM on the day of supplementation. The controls contained vehicle only.

\section{CT1 cell number assay}

CT1 cells were seeded at low confluency $\left(1 \times 10^{5}\right.$ cells/ $\mathrm{ml})$ into 24 -well Matrigel ${ }^{\mathrm{TM}}$ coated plates $(1 \mathrm{mg} / \mathrm{ml})$ and incubated for $48 \mathrm{~h}$ to permit cell adherence to the Matrigel. Serum-free medium containing 0, 0.1, 1, 10, or $100 \mathrm{ng} / \mathrm{ml}$ rhBMP2 or rhBMP4 was added to cultures (4 wells/treatment; 3 replicate studies). Forty-eight hours later the reduction of a tetrazolium compound (MTS) into a colored formazon product was used to quantify viable cell numbers. Color intensity at $490 \mathrm{~nm}$ was measured after 30 min incubation (Cell Titer 96 Aqueous One Solution Cell Proliferation Assay; Promega Corp., Madison, WI). Visual assessment at the time of the MTS treatment indicated that confluency was $>50 \%$ in each replicate study.

\section{Quantitative (q) RT-PCR}

RNA concentration and integrity were evaluated, and samples (10 ng/reaction; $A_{260} / 280$ ratio $\left.\geq 1.8\right)$ were incubated in RNase-free DNase (New England Biolabs, Ipswich, MA) for $30 \mathrm{~min}$ at $37^{\circ} \mathrm{C}$ followed by heat inactivation for $10 \mathrm{~min}$ at $75^{\circ} \mathrm{C}$. Reverse transcription and TaqMan PCR was completed as described previously [18] using an IFNT primer-probe set that recognizes all known bovine IFNT isoforms (a MNC-specific transcript) or a primer-probe set specific for $\mathrm{CSH} 1$ (chorionic somatomammotropic hormone; also known as placental lactogen), a binucleate cell-specific transcript [19] (Table 2). Both probes were labeled with a fluorescent 5' 6-FAM reporter dye and 3' TAMRA quencher (Life Technologies). Reactions also examined $18 S$ RNA abundance (reference control) (18S RNA Control Reagent Kit, 5'-VIC-labeled probe, Life Technologies). This reference was chosen based on previous studies [18] and because its mRNA concentrations were not impacted by treatments. After an initial activation/ denaturation step $\left(50^{\circ} \mathrm{C}\right.$ for $2 \mathrm{~min} ; 95^{\circ} \mathrm{C}$ for $\left.10 \mathrm{~min}\right), 40$ cycles of a two-step amplification procedure $\left(60^{\circ} \mathrm{C}\right.$ for 1

Table 2 Primer and probe sets used for qRT-PCR

\begin{tabular}{lll}
\hline Gene of Interest & $\begin{array}{l}\text { Primer/ } \\
\text { Probe }\end{array}$ & Sequence $\left(\mathbf{5}^{\prime} \mathbf{- 3}^{\prime}\right)^{\text {a }}$ \\
\hline IFNT $^{b}$ & $\begin{array}{l}\text { Forward } \\
\text { Reverse }\end{array}$ & TGCAGGACAGAAAAGACTTGGT \\
& CCTGATCCTTCTGGAGCTGG \\
& TTCCTCAGGAGATGGTGGTAGGGCA \\
\hline CSH1 & Forward & GTGGATTGTGACCTTGTTGA \\
& $\begin{array}{l}\text { Reverse } \\
\text { Probe }\end{array}$ & CCTGGCACAAGAGTAGATTGACA \\
& TCCTGCCTGCTCCTGCTGCTGGTA \\
\hline
\end{tabular}

aEach probe was synthesized with a 6-FAM reporter dye and TAMRA quencher ${ }^{b}[15]$ min; $95^{\circ} \mathrm{C}$ for $\left.15 \mathrm{~s}\right)$ was completed using a 7300 RealTime PCR System (Applied Biosystems, Life Technologies). Each RNA sample was analyzed in triplicate. A DNase-treated RNA not exposed to reverse transcriptase was included for each sample ensures samples were free of genomic DNA contamination. The $\Delta C_{t}$ method was used to examine the relative abundance of IFNT and CSH1 transcripts with that of 18S RNA [18].

\section{Statistical analyses}

All analyses were completed by using the General Linear Model of analysis of variance from the Statistical Analysis System (SAS Institute, Cary, NC). For qRT-PCR analysis, $\Delta C_{\mathrm{T}}$ values were used for analyses and data were graphed by examining fold-effect $[15,16]$. Results are presented as arithmetic means \pm SEM.

\section{Results and discussion}

The first set of studies examined whether the various components of the BMP2/4 ligand-receptor system were expressed in elongated conceptuses and CT1 cells. A single sample of RNA collected from endometria of pregnant cows was included as a positive control.

Transcripts for $B M P 2$ and BMP4 were readily detectable in elongated conceptuses and CT1 cells (Figure 1A). Transcripts for NOG were detected in elongated conceptuses but were either absent or detected at very low levels in CT1 cells (Figure 1A). Ectoderm and mesoderm expression of NOG is evident during gastrulation in other species [20], therefore it seems likely that the trophectoderm is not a primary source of NOG. It is interesting that transcripts for NOG could not be amplified from bovine endometrium (Figure 1A). Transcripts for NOG also could not be detected in other endometrial preparations obtained from cows in early pregnancy (days 14-17) (data not shown). Transcripts for NOG can be detected with in situ hybridization in mouse endometrium around the time of implantation, but the pattern of expression is restricted to stroma immediately underlying the epithelium [21]. Perhaps too little NOG mRNA exists in bovine endometrium for suitable amplification using conventional RT-PCR. Alternatively, perhaps the cow differs from mice and lacks endometrial NOG expression.

Transcripts for various BMP2 and 4 receptors subtypes also were detected in conceptuses and CT1 cells (Figure 1B). The TGF $\beta$ receptors are heterodimeric complexes comprised of two serine/threonine kinase receptor classes (type I and II). After ligand binding the type II receptor phosphorylates the type I receptor, which then initiates Smads and other intracellular transduction systems [22,23]. Bone morphogenetic proteins 2 and 4 interact with two specific type I receptors, termed BMPR1A (ALK3) and BMPR1B (ALK6), and a single 


\section{A}

Day 17 Conc. CT1 Cells Endo
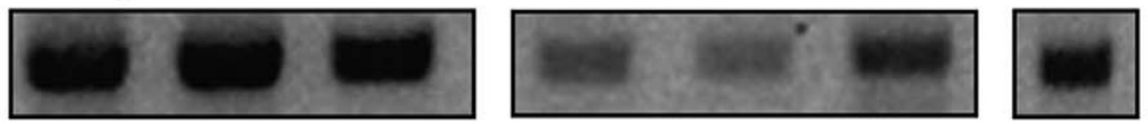

$B M P 2$
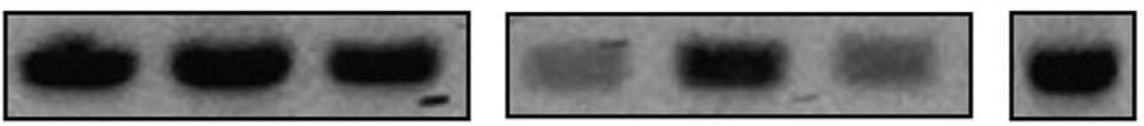

BMP4
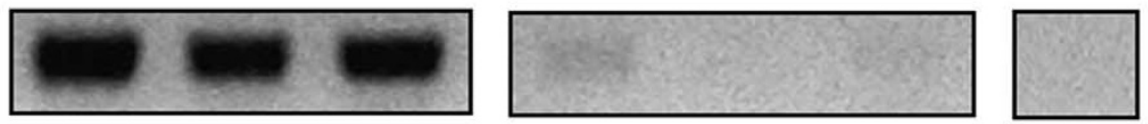

$N O G$
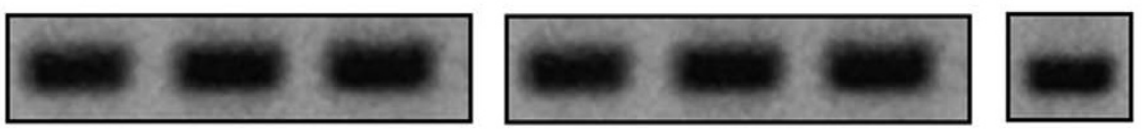

$A C T B$

B
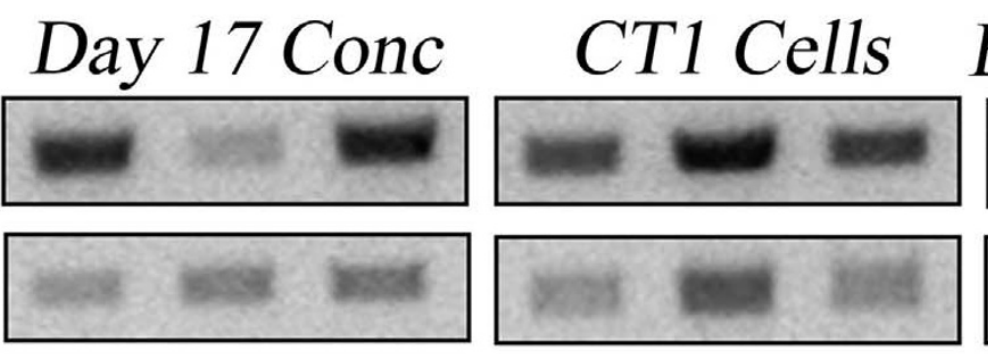

Endo
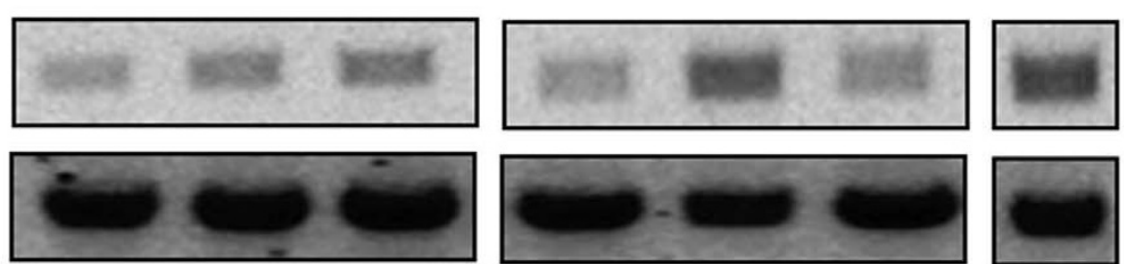

BMPRII
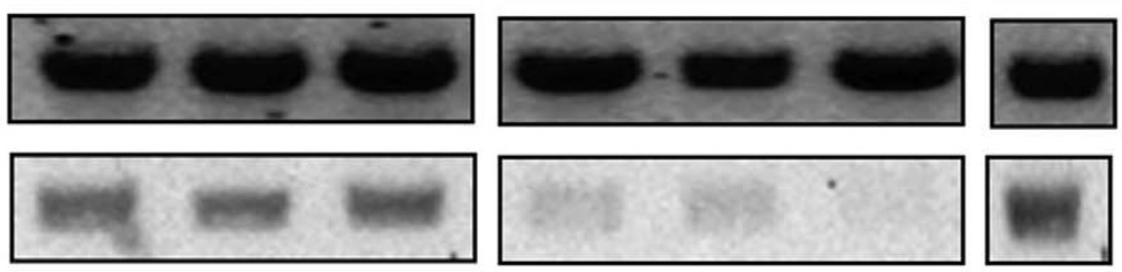

$B M P R 1 B$
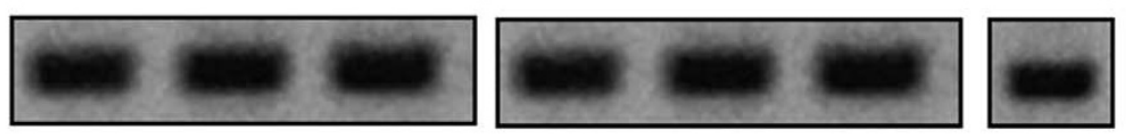

$A C T B$

Figure 1 End-point RT-PCR analysis of transcripts for bovine BMP ligands and receptors in the peri-attachment conceptus (day 17 post-insemination), trophoblast cells (CT1) and endometrium (Endo.). After RT-PCR, reactions were electrophoresed in 1\% [W/V] agarose containing ethidium bromide and amplicons were visualized using UV light. Three different conceptus and CT1 RNA preparations were used in each reaction but only a single endometrium RNA sample collected from cyclic cows at day 17 post-estrus was included. Panel A depicts BMP ligands and inhibitors. Panel B depicts BMP2/4 receptors. ACTB was included as a positive control. 
type II receptor termed BMPRII [24,25]. Bone morphogenetic protein 2 also reacts with a third type I receptor subunit termed ACVR1 (ALK2) [26]. Transcripts for each of these receptor subtypes were detected in elongated conceptuses and endometrium (Figure 1B). The CT1 cells also contained the receptor machinery needed to respond to BMP2 and 4, although they appeared to contain very little $B M P R 1 B$. This receptor subtype is not required for normal placental formation in mice [27].

New roles for BMP4 in trophoblast lineage specification have emerged in the past several years. Trophoblast lineages are generated from human ESCs by BMP4 supplementation $[28,29]$ and trophoblast development from bovine blastocyst outgrowths is stimulated by BMP4 [11]. However, potential functions for BMP2 and 4 after trophoblast specification have not been examined in cattle. The first study in this series of experiments examined whether BMP2 or BMP4 supplementation influenced CT1 cell growth (Figure 2). Supplementation with BMP2 did not affect viable cell numbers, but supplementation with 1,10 or $100 \mathrm{ng} / \mathrm{ml} \mathrm{BMP} 4$ reduced ( $\mathrm{P}$ $<0.05$ ) CT1 cell number after $48 \mathrm{~h}$ (Figure 2). Cells treated with BMP4 did not display any overt microscopic evidence of apoptosis or necrosis (detached, swollen/shriveled or punctated cells). Follow-up studies to quantify apoptosis and proliferation rates were not completed.

Another set of studies examined whether CT1 cells underwent any developmental modifications after supplementing serum free medium with $0.1,1,10$ or 100 $\mathrm{ng} / \mathrm{ml}$ BMP2 or BMP4. Microscopic examination of CT1 cells in various studies failed to detect changes in the incidence of $\mathrm{BNC}$ formation $(<2 \%$ in all groups; data not shown). Moreover, CSH1 transcripts could not be detected in CT1 cells after 48 or 96 h supplementation with BMP2 or 4 (data not shown). A mid-gestation placental RNA preparation was used to verify that CSH1 primers worked properly. The lack of detectable changes in trophoblast morphology and differentiation-dependent gene expression changes suggests that these factors may not be directly linked with trophoblast differentiation. However, limited effort has been devoted to uncovering ways to maximize $\mathrm{BNC}$ formation and $\mathrm{BNC}$ specific gene expression in these cells. Therefore, a possible association between these BMPs and bovine trophoblast differentiation cannot be dismissed.

A final study determined that exposure to BMP2 or 4 decreased $(\mathrm{P}<0.05)$ the relative abundance of IFNT mRNA (Figure 3). The minimal effective concentration needed to achieve this effect was less for BMP2 (10 ng/ $\mathrm{ml})$ than BMP4 $(100 \mathrm{ng} / \mathrm{ml})$. Expression of IFNT was decreased in a dose-dependent manner by BMP2 but not by BMP4. These outcomes suggest that BMP2 may be a more potent inhibitor of IFNT expression than BMP4. Changes in the synthesis and secretion of IFNT protein were not determined since IFNT mRNA abundance is usually reflective of protein production [16]. Interferon-tau exhibits a biphasic expression pattern during early pregnancy, where the amounts of IFNT mRNA increase dramatically around the time of conceptus elongation (day 13-15 in cattle) and decrease rapidly approximately one week later as implantation begins [30]. Several uterine- and conceptus-derived factors such as fibroblast growth factors (e.g. FGF2, 10) and colony stimulating factor 2 stimulate IFNT production from bovine trophectoderm [16,18,31,32]. These and
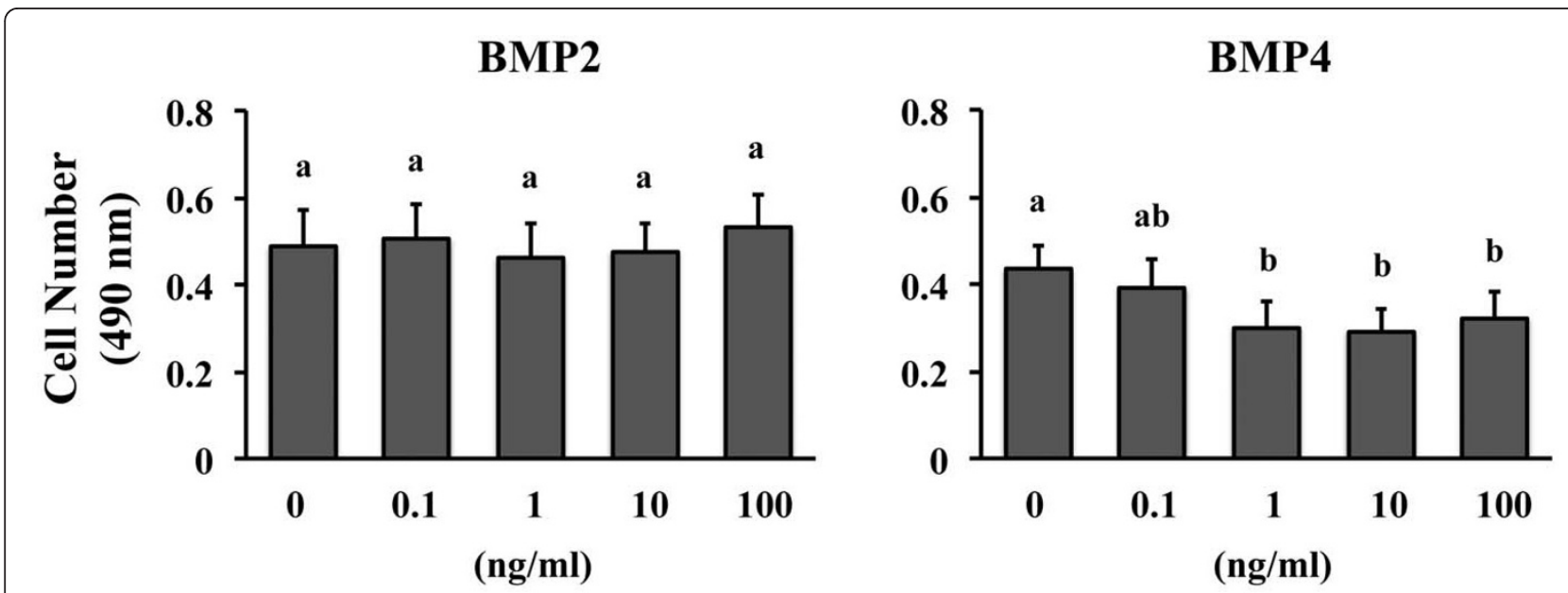

Figure 2 Effect of BMP2 or BMP4 supplementation on CT1 cell survival. CT1 cells were supplemented with various concentrations of BMP2 (left panel) or BMP4 (right panel) for $48 \mathrm{~h}$, then viable cell numbers were quantified by examining the metabolism a tetrazolium compound (MTS) into a colored formazon product visible at $490 \mathrm{~nm}(\mathrm{n}=4$ replicate studies for each BMP). Different superscripts within each BMP treatment denote differences $(P<0.05)$. 


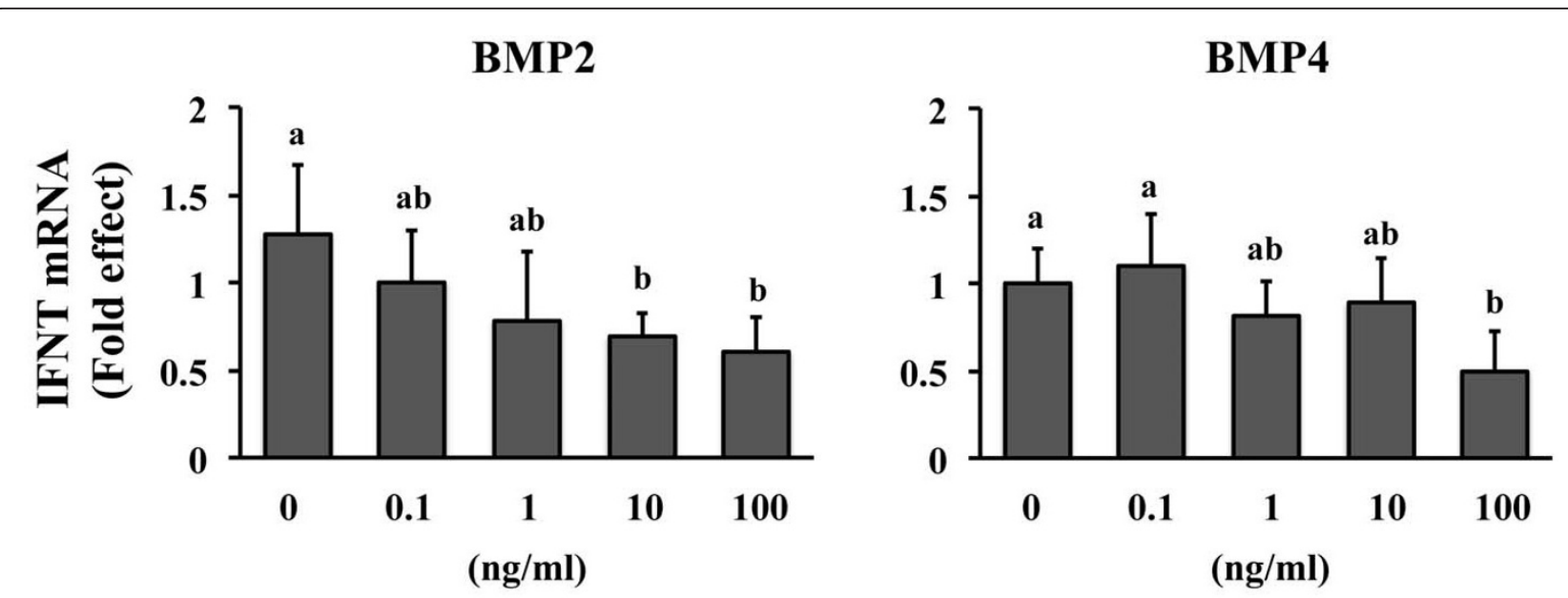

Figure 3 Effect of BMP2 and BMP4 supplementation on IFNT mRNA abundance in CT1 cells. Cells were supplemented with various concentrations of BMP2 (left panel) or BMP4 (right panel) for $24 \mathrm{~h}$, then RNA was extracted and GRT-PCR was completed. $18 \mathrm{~s}$ RNA was used as the reference control. Data are presented as fold-differences from non-treated controls ( $n=4$ replicate studies for each BMP). Different superscripts within each BMP treatment denote differences $(P<0.05)$.

other factors may play a part in the rapid increase in IFNT production during elongation. The identity of uterine and conceptus factors functioning as negative regulators of IFNT expression remained undetermined. Perhaps BMP2 and 4 may function as implantationdependent down regulators of IFNT expression. However, the magnitude of the reduction in IFNT mRNA was not great $(<2$-fold reduction) and it is not clear whether the large amounts of BMP supplementation needed to detect this effect have any physiological relevance.

In conclusion, ligands and receptors for BMP2 and 4 are expressed in elongating conceptuses and the CT1 cell line. No detectable changes in cell morphology or differentiation were detected after CT1 exposure to these BMPs. However, supplementation with BMP2 or 4 decreased cell growth rates and IFNT mRNA abundance. These observations implicate BMP2 and 4 as uterine and conceptus mediators of trophoblast development and IFNT production around the time of implantation.

\section{Author information}

Current address for Dr. Kathleen Pennington; Division of Reproductive and Perinatal Research, Department of Ob-GYN and Women's Health, University of Missouri, Columbia, MO 65212

\section{Acknowledgements}

This project was supported by National Research Initiative Competitive Grant no. 2008-35203-19106 from the USDA National Institute of Food and Agriculture.

\section{Authors' contributions}

KAP assisted in the design of the studies, completed each of the studies, participated in the analysis and interpretation of the findings, and drafted the manuscript. ADE acquired funding for the project, assisted in the design of the studies, participated in the analysis and interpretation of the findings and generated the final draft of the manuscript. All authors read and approved the final manuscript.

\section{Competing interests}

The authors declare that they have no competing interests.

Received: 29 November 2011 Accepted: 13 February 2012 Published: 13 February 2012

\section{References}

1. Kitisin K, Saha T, Blake T, Golestaneh N, Deng M, Kim C, Tang Y, Shetty K, Mishra B, Mishra L: Tgf-Beta signaling in development. Sci STKE 2007, 2007(399): $\mathrm{cm} 1$.

2. Robert B: Bone morphogenetic protein signaling in limb outgrowth and patterning. Dev Growth Differ 2007, 49(6):455-468.

3. Shimasaki S, Moore RK, Otsuka F, Erickson GF: The bone morphogenetic protein system in mammalian reproduction. Endocr Rev 2004, 25(1):72-101.

4. Fujiwara T, Dunn NR, Hogan BL: Bone morphogenetic protein 4 in the extraembryonic mesoderm is required for allantois development and the localization and survival of primordial germ cells in the mouse. Proc Natl Acad Sci USA 2001, 98(24):13739-13744.

5. Murohashi M, Nakamura T, Tanaka S, Ichise T, Yoshida N, Yamamoto T, Shibuya M, Schlessinger J, Gotoh N: An FGF4-FRS2alpha-Cdx2 axis in trophoblast stem cells induces Bmp4 to regulate proper growth of early mouse embryos. Stem Cells 2010, 28(1):113-121.

6. Winnier G, Blessing M, Labosky PA, Hogan BL: Bone morphogenetic protein-4 is required for mesoderm formation and patterning in the mouse. Genes Dev 1995, 9(17):2105-2116.

7. Mishina Y, Suzuki A, Gilbert DJ, Copeland NG, Jenkins NA, Ueno N, Behringer RR: Genomic organization and chromosomal location of the mouse type I BMP-2/4 receptor. Biochem Biophys Res Commun 1995, 206(1):310-317.

8. Mishina Y, Suzuki A, Gilbert DJ, Copeland NG, Jenkins NA, Ueno N, Behringer RR: Genomic organization and chromosomal location of the mouse type I BMP-2/4 receptor. Biochem Biophys Res Commun 1995, 206(1):310-317. 
9. Xu RH, Chen X, Li DS, Li R, Addicks GC, Glennon C, Zwaka TP, Thomson JA: BMP4 initiates human embryonic stem cell differentiation to trophoblast. Nat Biotechnol 2002, 20(12):1261-1264.

10. Schulz LC, Ezashi T, Das P, Westfall SD, Livingston KA, Roberts RM: Human embryonic stem cells as models for trophoblast differentiation. Placenta 2008, 29:S10-S16.

11. Suzuki Y, Koshi K, Imai K, Takahashi T, Kizaki K, Hashizume K: Bone morphogenetic protein-4 accelerates the establishment of bovine trophoblastic cell lines. Reproduction 2011, 142(5):733-743.

12. Ealy $A D$, Yang $Q E$ : Control of interferon-tau expression during early pregnancy in ruminants. Am J Reprod Immunol 2009, 61(2):95-106.

13. Talbot NC, Caperna TJ, Edwards JL, Garrett W, Wells KD, Ealy AD: Bovine blastocyst-derived trophectoderm and endoderm cell cultures: interferon tau and transferrin expression as respective in vitro markers. Biol Reprod 2000, 62(2):235-247.

14. Talbot NC, Powell AM, Camp M, Ealy AD: Establishment of a bovine blastocyst-derived cell line collection for the comparative analysis of embryos created in vivo and by in vitro fertilization, somatic cell nuclear transfer, or parthenogenetic activation. In Vitro Cell Dev Biol Anim 2007, 43(2):59-71.

15. Cooke FNT, Pennington KA, Yang Q, Ealy AD: Several fibroblast growth factors are expressed during pre-attachment bovine conceptus development and regulate interferon-tau expression from trophectoderm. Reproduction 2009, 137(2):259-269.

16. Michael DD, Alvarez IM, Ocon OM, Powell AM, Talbot NC, Johnson SE, Ealy AD: Fibroblast growth factor- 2 is expressed by the bovine uterus and stimulates interferon-tau production in bovine trophectoderm. Endocrinology 2006, 147(7):3571-3579.

17. Talbot NC, Caperna TJ, Edwards JL, Garrett W, Wells KD, Ealy AD: Bovine blastocyst-derived trophectoderm and endoderm cell cultures: interferon tau and transferrin expression as respective in vitro markers. Biol Reprod 2000, 62(2):235-247.

18. Cooke FN, Pennington KA, Yang Q, Ealy AD: Several fibroblast growth factors are expressed during pre-attachment bovine conceptus development and regulate interferon-tau expression from trophectoderm. Reproduction 2009, 137(2):259-269.

19. Hashizume K, Ushizawa K, Patel OV, Kizaki K, Imai K, Yamada O, Nakano H, Takahashi T: Gene expression and maintenance of pregnancy in bovine: roles of trophoblastic binucleate cell-specific molecules. Reprod Fertil Dev 2007, 19(1):79-90.

20. Krause C, Guzman A, Knaus P: Noggin. Int J Biochem Cell Biol 2011, 43(4):478-481.

21. Paria BC, Ma W, Tan J, Raja S, Das SK, Dey SK, Hogan BL: Cellular and molecular responses of the uterus to embryo implantation can be elicited by locally applied growth factors. Proc Natl Acad Sci USA 2001, 98(3):1047-1052.

22. Massague J, Seoane J, Wotton D: Smad transcription factors. Genes Dev 2005, 19(23):2783-2810.

23. Nohe A, Keating E, Knaus P, Petersen NO: Signal transduction of bone morphogenetic protein receptors. Cell Signal 2004, 16(3):291-299.

24. Koenig BB, Cook JS, Wolsing DH, Ting J, Tiesman JP, Correa PE, Olson CA, Pecquet AL, Ventura FS, Grant RA, et al: Characterization and cloning of a receptor for BMP-2 and BMP-4 from NIH 3T3 cells. Mol Cell Biol 1994, 14(9):5961-5974.

25. ten Dijke P, Yamashita H, Sampath TK, Reddi AH, Estevez M, Riddle DL, Ichijo $\mathrm{H}$, Heldin $\mathrm{CH}$, Miyazono K: Identification of type I receptors for osteogenic protein-1 and bone morphogenetic protein-4. J Biol Chem 1994, 269(25):16985-16988.

26. Lee KB, Khivansara V, Santos MM, Lamba P, Yuen T, Sealfon SC, Bernard DJ: Bone morphogenetic protein 2 and activin A synergistically stimulate follicle-stimulating hormone beta subunit transcription. $J \mathrm{Mol}$ Endocrinol 2007, 38(1-2):315-330.

27. Goumans MJ, Mummery C: Functional analysis of the TGFbeta receptor/ Smad pathway through gene ablation in mice. Int J Dev Biol 2000, 44(3):253-265

28. Das P, Ezashi T, Schulz LC, Westfall SD, Livingston KA, Roberts RM: Effects of fgf2 and oxygen in the bmp4-driven differentiation of trophoblast from human embryonic stem cells. Stem Cell Res 2007, 1(1):61-74.

29. Schulz LC, Ezashi T, Das P, Westfall SD, Livingston KA, Roberts RM: Human embryonic stem cells as models for trophoblast differentiation. Placenta 2008, 29(Suppl A):S10-S16.
30. Ealy AD, Yang QE: Control of Interferon-Tau expression during early pregnancy in Ruminants. Am J Reprod Immunol 2009, 61(2):95-106.

31. Michael DD, Wagner SK, Ocon OM, Talbot NC, Rooke JA, Ealy AD: Granulocyte-macrophage colony-stimulating-factor increases interferontau protein secretion in bovine trophectoderm cells. Am J Reprod Immunol 2006, 56(1):63-67.

32. Loureiro B, Block J, Favoreto MG, Carambula S, Pennington KA, Ealy AD Hansen PJ: Consequences of conceptus exposure to colony-stimulating factor 2 on survival, elongation, interferon-\{tau\} secretion, and gene expression. Reproduction 2011, 141(5):617-624.

doi:10.1186/1477-7827-10-12

Cite this article as: Pennington and Ealy: The expression and potential function of bone morphogenetic proteins 2 and 4 in bovine trophectoderm. Reproductive Biology and Endocrinology 2012 10:12.

\section{Submit your next manuscript to BioMed Central and take full advantage of:}

- Convenient online submission

- Thorough peer review

- No space constraints or color figure charges

- Immediate publication on acceptance

- Inclusion in PubMed, CAS, Scopus and Google Scholar

- Research which is freely available for redistribution

Submit your manuscript at www.biomedcentral.com/submit
Biomed Central 